\title{
REVIEW OF THE SPECIES GROUPS \\ OF THE GENUS CTENOCERATODA VARGA, 1992 WITH DESCRIPTION OF FOUR NEW SPECIES AND A NEW SUBSPECIES (LEPIDOPTERA, NOCTUIDAE)
}

\author{
Zoltán VARGA ${ }^{1}$, Péter Gyulai ${ }^{2}$, GÁbor RonkaY ${ }^{3}$ and LÁsZló RonkaY ${ }^{4}$ \\ ${ }^{1}$ Department of Evolutionary Zoology and Human Biology, University of Debrecen \\ H-4010 Debrecen, Hungary; E-mail: varga.zoltan@science.unideb.hu \\ ${ }^{2}$ H-3530 Miskolc, Mélyvölgy 13/A, Hungary; E-mail: gyulainegarai.adrienne@upcmail.hu \\ ${ }^{3}$ Heterocera Press Ltd., H-1137 Budapest, Szent István krt. 4, Hungary \\ E-mail: gaborronkay@gmail.com \\ ${ }^{4}$ Department of Zoology, Hungarian Natural History Museum \\ H-1088 Budapest, Baross u. 13, Hungary; E-mail: ronkay.laszlo@nhmus.hu
}

The taxonomic position of the genus Ctenoceratoda Varga, 1992 is discussed; the different species groups of it are reconsidered, their diagnoses and the revised taxonomic content of all species groups is given. Four new species and one new subspecies are described; their external morphology and genital structures are illustrated.

Key words: Ctenoceratoda, species groups, new species and subspecies, genital characters, allopatry.

\section{INTRODUCTION}

The subtribe Poliina of the tribe Hadenini (subfamily Noctuinae sec. LAFONTAINe \& SCHMidt 2010) was originally defined as „Polia complex" by McCABE (1980) based on the genital characters of both sexes. Subsequently, this clade was first re-defined and separated from the closely related Mamestrina by Веск (1996), later by Hacker et al. (2002) and Fibiger and Hacker (2005). The subtribe consists of, according to the re-description and interpretation provided in the latter work, the genera Polia Ochsenheimer, 1816 (incl. as synonyms: Chera Hübner, [1821]; Polia Boisduval, 1829, Aplecta Guenée, 1838, Anartodes Culot, 1915, Bompolia Beck, 1999, Ripolia Beck, 1999, Antipolia Beck, 1999), Pachetra Guenée, 1841, Kollariana Hacker, 1996, Haderonia Staudinger, 1896 (=Lasiridia Draudt, 1950), Ctenoceratoda Varga, 1992 and Tricheurois Hampson, 1905. From these genera, Kollariana should be excluded from the subtribe as it belongs to Mamestrina, being closely related to the Sideridis Hübner, 1821 generic complex (see VARGA et al. 2017).

The members of this subtribe have generally identical "ground plan" of genital structures including some lock-and-key mechanisms (e.g. VARGA 1992, VARGA \& RoNKAY 2013) with several shared apomorphies as the identical 
structure of ampulla-harpe complex, the regularly asymmetrical saccular processes covered by specialised brushes, the long and tubular vesica (endophallus) without subbasal diverticulum and cornutus but with a long medio-subterminal field of fasciculate cornuti (males), the globular corpus bursae and in most cases the long, tubular appendix bursae (females). Paired abdominal brush-organs of males are usually present though may be reduced in certain lineages and the last abdominal segment of females regularly shows specific, often shield-shaped sclerotised structures.

The genus Ctenoceratoda Varga, 1992 was separated from Haderonia Staudinger, 1896 (type species: Haderonia subarschanica Staudinger, 1895 by monotypy) based on significant differences in genitalia of both sexes, different external look and very long, in male typically strongly bipectinate antennae (see the derivatio nominis). The very sophisticated lock-and-key apparatus of the vesica and the corpus/appendix bursae complex occurring in all species, in combination with certain simplifications of the completely symmetrical genital capsule were considered as main generic traits, which allow a clear differentiation both from the closest related genera, Haderonia and Polia.

Based on these characters, eleven Haderonia species (sensu Boursin 1964) were transferred to the newly erected genus (VARGA 1992) and additional four new species have been described. Some years later, VARGA and GYulaI (1999) defined ten basic characters of the genus, partly shared with Polia and Haderonia as tentative synapomorphies, and considered these genera as forming a larger monophyletic unit together with Ctenoceratoda. The species content of the genus has been remarkably increased in this work with the descriptions of seven new species.

Present paper is aimed to distinguish and characterise the major lineages of Ctenoceratoda, designate the lectotypes of taxonomically problematic species in order to define their taxonomic identity and to describe further five new taxa from Central Asia and the western Himalayas as well.

\section{TAXONOMIC REVIEW}

The re-definition of the species groups of Ctenoceratoda is given below without any subgeneric subdivision, including also the recently described species, since all species have preserved the generic characters with only minor variations. We provide here a short diagnosis of each species group. Therefore, this phenetic grouping cannot be interpreted as a phylogenetic subdivision but as a pre-conception for the further, monographic treatment. For practical reasons we start this survey with the species group including the type-species of genus. 


\section{The sukharevae-group}

Diagnosis - Relatively large moths with robust body, very long, in male strongly (sukharevae, oxyptera, juliannae) or shortly (longicornis, lukhtanovi, stenocera) bipectinate antennae and elongate triangular forewings with colourful appearance. The noctuid forewing pattern is complete and regular, in some species sharply expressed (sukharevae, oxyptera, juliannae), in others rather faint (lukhtanovi, stenocera). Male brush organ reduced.

Male genitalia - uncus mostly short and acute triangular (exceptionally obtuse in lukhtanovi); valvae with normally developed rounded cucullus and corona without incision, short and broad ampulla (exception: oxyptera). Saccular processes symmetrical, short and obtuse. Species of this group can be mostly differentiated by the length of pectination of male antennae, by the shape and length of uncus and ampulla but also by the length of the field of fasciculate cornuti on the distal part of the tubular vesica.

\section{Checklist}

Ctenoceratoda longicornis (Graeser, 1892, Mamestra), Berliner Entomologische Zeitschrift 37: 306.Type-locality: [Kirghisia] Kysyl-Yart; [China, Xinjiang] Kashgar;

Ctenoceratoda sukharevae (Varga, 1974, Haderonia), Annales historico-naturales Musei nationalis hungarici 66: 301, pl. 7, fig. 7. Type-locality: Mongolia, Bayankhongor aimak, Zhinst Mts;

Haderonia sukharevae excellens (Varga, 1974, Haderonia), Annales historico-naturales Musei nationalis hungarici 66: 302, pl. 1, figs 7-8.Type-locality: Mongolia, Khövsgöl aimak, Delger Mörön River;

Ctenoceratoda oxyptera Varga, 1992, Acta Zoologica Academiae Scientiarum Hungaricae 38 (1-2): 99, pl. 3, figs 17-18, gen. figs 37-43.Type-locality: Mongolia, Govi Altai aimak, Govi Altai Mts;

Ctenoceratoda juliannae Varga, 1992, Acta Zoologica Academiae Scientiarum Hungaricae 38 (12): 99, pl. 3, fig. 19, gen. figs 33-36. Type-locality: Mongolia, Khovd aimak, Dzhungar Govi, Bulgan sum;

Ctenoceratoda lukhtanovi Varga et Gyulai, 1999, Acta Zoologica Academiae Scientiarum Hungaricae 45(2): 172, figs 1-2, 23, 41, 50-52, 82. Type-locality: Tadjikistan, Pamir Mts, Muzkol Mts, Ak-Baital Pass;

Ctenoceratoda stenocera Varga et Gyulai, 2002, Esperiana 9: 230, pl. 20, fig. 16. Type-locality: China, Kunlun Mts, 60 km NW of Xaidullah village.

Bionomics and distribution - A mostly Inner Asiatic species group, typical for extreme cold-continental semi-desert or rupicolous habitats in medium or high altitudes. 


\section{The khorgossi-group}

Diagnosis - This species-group is most similar in its external and genital characters to the sukharevae-group. They are medium-sized moths with robust body, very long and strongly bipectinated male antennae and relatively narrow triangular, apically acute forewings with brownish-bluish-ochreous or silvery grey variegated colouration. Orbicular and reniform stigmata conspicuous, reniform stigma often with acute "pipe-shaped" extension in basal direction, orbicular stigma narrow and oblique. Male brush organ reduced.

In the male genitalia, the uncus is relatively short, triangular, pointed apically, the cucullus is rounded triangular or slightly inflated with narrow neck and regular corona; the ampulla is mostly elongate, acute or obtuse. In male vesica the stripe of fasciculate cornuti and in females the sausage-shaped appendix bursae are relatively short.

\section{Checklist}

Ctenoceratoda khorgossi (Alphéraky, 1882, Mamestra), Horae Societatis Entomologicae Rossicae 17: 65, pl. 2, fig. 49. Type-locality: [China, Xinjiang] Kuldja district; Khorgoss;

Ctenoceratoda argyrea Varga, 1992, Acta Zoologica Academiae Scientiarum Hungaricae 38(1-2):

98, pl. 2, figs 9-10, gen. figs 5-10, 16-17.Type-locality: Mongolia, Govi Altai aimak, Govi Altai Mts;

Ctenoceratoda persephone sp. $\mathbf{n}$.

Ctenoceratoda scotosparsa sp. $\mathbf{n}$.

Bionomics and distribution - One species of the group is widely distributed in Central Asia, the range of three others seems to be confined to western Mongolia with some phenological and vertical differentiation.

\section{The tancrei-group}

Diagnosis - Medium-sized or large moths with robust body, very long and strongly bipectinated male antennae and elongated-triangular forewings. Colouration of forewings mostly greyish-ochreous-brownish, rarely rufous with regular but often faint maculation. Reniform stigma often shows an acute whitish stripe basally. Male brush organ regularly present.

In the male genitalia, the uncus is relatively long, the cucullus is rounded triangular, often slightly inflated or with small incision; the ampulla is elongate, more or less curved. Vesica tubular, extremely long with long stripe of fasciculate cornuti.

The species of this group can be recognised externally by the greyish or rufous-brownish colouration, the presence or absence of whitish marking at 
the basal part of the reniform stigma. The group features of the male genitalia are the characteristic shape of the "head" of cucullus, and configuration of the ampulla and the length of the fascia of cornuti in the vesica.

\section{Checklist}

Ctenoceratoda tancrei (Graeser, 1892, Mamestra), Berliner Entomologische Zeitschrift 37: 305. Type-locality: [Kirghisia] Alexander Mts;

Ctenoceratoda graeseri (Püngeler, 1898, Haderonia, tancrei var.), Societas Entomologica 13: 58. Type-locality: [Kazakhstan or China] Ili region;

Ctenoceratoda thermolimna (Boursin, 1964, Haderonia), Zeitschrift der Wiener Entomologischen Gesellschaft 49: 174, pl. 22, figs 1, 4. Type-locality: Kirghisia, Issyk-Kul;

Ctenoceratoda anthracina Varga et Gyulai, 1999, Acta Zoologica Academiae Scientiarum Hungaricae 45 (2): 180, figs 12-13. Type-locality: Kirghisia, Naryn region, Maly Naryn;

Ctenoceratoda naryna Varga et Gyulai, 1999, Acta Zoologica Academiae Scientiarum Hungaricae 45 (2): 189, figs 15-16, 33, 47, 66-67, 87. Type-locality: Kirghisia, Naryn region, Maly Naryn;

Ctenoceratoda transalaica Varga et Gyulai, 1999, Acta Zoologica Academiae Scientiarum Hungaricae 45 (2): 189, figs 17, 34, 48, 68-69, 88. Type-locality: Kirghisia, Transalai, AramKungei.

Ctenoceratoda cyanochrea sp. $\mathbf{n}$.

Bionomics and distribution - Almost all species are confined to the TienShan mountain system where they are mostly typical for the semi-desert like habitats of low or moderate altitudes (contrasting to the next group!). Two species are relatively widely distributed in Central Asia (tancrei, graeseri), the other species seem to be rather localised and infrequent.

\section{The turpis-group}

Diagnosis - Large or medium-sized moths with not extremely long and moderately or strongly bipectinated male antennae, moderately elongate, apically acute forewings. Colouration simple, nearly concolorous grey or brownish, markings regular, often faint. Male brush organ present.

In the male genitalia, uncus long and narrow; cucullus rounded triangular with moderately elongate "neck"; ampulla elongate, often slightly falcate. Since the genital capsule of the different members of the group is very similar, the pectination of antennae appears as important specific character.

\section{Checklist}

Ctenoceratoda turpis (Staudinger, 1900, Phoebophilus), Deutsche Entomologische Zeitschrift. Gesellschaft Iris zu Dresden 12: 341, pl. 7, fig. 8. Type-locality: [China, Xinjiang] Korla; 
Ctenoceratoda brassicina (Draudt, 1934, Scotogramma), in A. Seitz, Die Gross-Schmetterlinge der Erde 3: 98, pl. 14, row c. Type-locality: [Russia or Kazakhstan] "Altai occ.";

Ctenoceratoda gandhara (Hacker et Varga, 1990, Haderonia), Esperiana 1: 340, pl. E, fig. 16. Type-locality: Pakistan, Karakoram Mts, Kunjerab pass;

Ctenoceratoda weigerti (Hacker et Varga, 1990, Haderonia), Esperiana 1: 340, pl. E, fig. 17. Type-locality: Pakistan, Karakoram Mts, Kunjerab pass;

Ctenoceratoda peregovitsi Varga et Gyulai, 1999, Acta Zoologica Academiae Scientiarum Hungaricae 45(2): 174, figs 4-5, 25-26. Type-locality: Mongolia, Ömnögovi aimak, Tost Mts; Ctenoceratoda psychrogena Varga et Gyulai, 1999, Acta Zoologica Academiae Scientiarum Hungaricae 45(2): 175, figs 6-8, 27-29, 42-44, 58-62, 84. Type-locality: Tadjikistan, Pamir Mts, Vakhanskiy Mts;

Ctenoceratoda aksakal Varga et Gyulai, 1999, Acta Zoologica Academiae Scientiarum Hungaricae 45(2): 179, figs 11, 41, 57, 85. Type-locality: Tadjikistan, E Pamir Mts, Sarykolskiy Mts.

Bionomics and distribution - All species are confined to the high mountains of Central and Inner Asia, they regularly occur in high altitudes.

\section{The lupa-group}

Diagnosis - Large moths with robust body, very long and strongly bipectinated male antennae, elongate and apically acute but relatively broad forewings. Patterns of fore wing are regular, contrasting, reniform and claviform stigmata and the subterminal line are strongly expressed, basal part of reniform stigma usually defined with blackish-brown scales. Abdominal brush organ well-developed.

Female abdomen bears characteristic "lanuginose" terminal tuft, analogous with some Lymantriinae spp., possibly having role in the defence of eggs (see the etymology of the new species).

In the male genitalia, the uncus is short, acute triangular; the valvae have slightly elongate saccular process and very long "neck" of the relatively small, rounded cucullus. Ampulla relatively long with some specific variations, acute or obtuse; aedeagus and vesica very long, with long and relatively narrow field of fasciculate cornuti. In female genitalia the appendix bursae is extremely elongate, slightly saccate terminally.

\section{Checklist}

Ctenoceratoda lupa (Christoph, 1893, Mamestra), Deutsche Entomologische Zeitschrift. Gesellschaft Iris zu Dresden 6: 91. Type-locality: [Iran] Hyrcania, Shahkuh;

Ctenoceratoda contempta (Püngeler, 1914, Hadula), Deutsche Entomologische Zeitschrift. Gesellschaft Iris zu Dresden 28: 39, pl. 2, fig. 14. Type-locality: [China, Xinjiang] "OstTurkestan, Aksu";

Ctenoceratoda septemlacustris Gaal-Haszler, Lödl, Ronkay, Ronkay et Varga, 2012, Fibigeriana 1: 125, pl. 112, figs 19-20, gen. figs 12-13. Type-locality: Afghanistan, Koh-i-Baba Mts, Band-i-Amir; 
Ctenoceratoda mallopyga sp. $\mathbf{n}$.

Ctenoceratoda mallopyga dyschroa ssp. $\mathbf{n}$.

Bionomics and distribution - Rather widely distributed species group, with its range extending from North Iran to the south-western part of the Himalayas. The moths inhabit a variety of habitat types in medium and high altitudes.

\section{The nefasta-group}

Diagnosis - A relatively poorly known species group since we have almost exclusively old, "classic" material from two (nefasta and optima) of the three species. Externally, the members of this lineage resemble the species of the sukharevae-group, but the structure of the male genitalia displays the closer relationship with the tancrei-group.

Medium-sized (nefasta and optima) or large (leucostigma) moths with robust body, long and strongly bipectinated male antennae, relatively broad forewings with ochreous-greyish ground colour and regular maculation.

In the male genitalia, the uncus is relatively short and acute, the ampulla is long and slightly falcate with acute or obtuse tip, the "neck" of cucullus is relatively long and the "head" is rounded, relatively small, without incision.

\section{Checklist}

Ctenoceratoda nefasta (Püngeler, 1907, Hadula), Deutsche Entomologische Zeitschrift. Gesellschaft Iris zu Dresden 19: 221, pl. 8, fig. 2. Type-locality: [China, Xinjiang] Lob-Noor;

Ctenoceratoda optima (Alphéraky, 1897, Haderonia), in Romanoff, Mémoires sur les Lépidoptéres 9: 236, pl. 12, fig. 7. Type-locality: [China] "Oulan-boulak, Nan-chan";

Ctenoceratoda leucostigma Gyulai et Varga, 2010, Folia entomologica hungarica 70: 182, figs 1-3, gen. figs 9-13. Type-locality: China, Qinghai [Kuku-Noor region], $20 \mathrm{~km} \mathrm{~N}$ of Da Qaidam city.

Bionomics and distribution - All species are confined to some extremely cold-continental parts of Inner Asia.

\section{The zetina-group}

Diagnosis - Large, robust moths, slightly resembling certain large Apamea species, with long and only shortly pectinate male antennae and elongatetriangular forewings with regular but often faint maculation and crenulate crosslines. Abdominal brush organ well-developed, having "pockets".

Male genitalia with strong, acute uncus, relatively short, falcate ampulla and inflated cucullus with deep incision above the terminal seta. Vesica is large, broad with long and broad stripe of fasciculate cornuti. 


\section{Checklist}

Ctenoceratoda zetina zetina (Staudinger, 1900, Hadena "zeta var."), Deutsche Entomologische Zeitschrift. Gesellschaft Iris zu Dresden 12: 342. Type-locality: [China or Kirghisia, Tien Shan region] "Thian or";

Ctenoceratoda zetina rhodoptera Varga, 1992, Acta Zoologica Academiae Scientiarum Hungaricae 38 (1-2): 100, pl. 1, fig. 7. Type-locality: Afghanistan central, Band-i-Amir;

Ctenoceratoda gyulaii Volynkin, 2012, Proceedings of the Tigirek State Natural Reserve 5: 205, pl.

3, figs 5-6; pl. 15, figs 18-23; pl. 28, figs 3-4; pl. 33, fig. 3. Type-locality: Russia, Altai Republic, Kosh-Agach district.

Bionomics and distribution - Ctenoceratoda zetina is one of the most widely distributed species of the genus, known from the nearly entire Tien-Shan system, the Pamirs, the Karakoram and the western Himalayas. Its sister species occurs in the Russian and the Mongolian parts of the Altai Mts. The possible overlap and/or hybridisation between them are unknown.

\section{LECTOTYPE DESIGNATIONS \\ Ctenoceratoda graeseri (Püngeler, 1898)}

(Fig. 16)

Haderonia tancrei var. graeseri Püngeler, 1898, Societas Entomologica 13: 58. Type-locality: [Kazakhstan or China] Ili region. Lectotype: male, here designated, in coll. MNHU.

Lectotype designation. Lectotype: male, "Ili 1897 M Juli". The lectotype was dissected by Boursin (slide MB, without number). Paralectotype: female, with the same locality and date.

\section{Ctenoceratoda lupa (Christoph, 1893)}

(Figs 21, 55, 56)

Mamestra lupa Christoph, 1893, Deutsche Entomologische Zeitschrift. Gesellschaft Iris zu Dresden 6: 91. Type-locality: [Iran] Hyrcania, Shahkuh. Lectotype: male, here designated; in coll. BMNH.

Lectotype designation. Lectotype: male, "Schahkuh", "Coll. Christoph [580]", “Ex Coll. H.J. Elwes, 1920.” “Joicey Bequest. Brit. Mus. 1934-120.”, “(NHMUK010354058)”; slide No. RL11751m (coll. BMNH).

\section{Ctenoceratoda contempta (Püngeler, 1914)}

(Figs 20, 51, 52)

Hadula (Mamestra) contempta Püngeler, 1914, Deutsche Entomologische Zeitschrift. Gesellschaft Iris zu Dresden 28: 39, pl. 2, fig. 14. Type-locality: [China, Xinjiang] “Ost-Turkestan, Aksu". Lectotype: male, here designated; in coll. MNHU. 
Lectotype designation. Lectotype: male, “O-Turkestan, Aksu", “910 R[ue]ckb[eil]". The specimen was dissected by Boursin (slide No. MB 810), in coll. MNHU.

\title{
DESCRIPTION OF THE NEW SPECIES
}

\section{Ctenoceratoda persephone sp. $\mathrm{n}$.}

\author{
(Figs 1-4, 25, 33, 34, 39)
}

Holotype: male, Mongolia, Khovd aimak, $60 \mathrm{~km}$ E of Altay somon centre, $1600 \mathrm{~m}, 45^{\circ} 48^{\prime} \mathrm{N}$, 9250’N, 19.V.1990. leg. Gy. Fábián, M. Hreblay, L. Peregovits \& G. Ronkay (coll. HNHM).

Paratypes. Mongolia. 14 males, 5 females, from the same locality and date (coll. Gy. Fábián, P. Gyulai, G. Ronkay \& HNHM); 7 males, Ömnögovi aimak, Mts Noyon, 22 km SE of Gurvantös, 1800 m, N43¹4', E101²7’, 13.V.1990, leg. Gy. Fábián, M. Hreblay, L. Peregovits \& G. Ronkay (coll. Gy. Fábián, G. Ronkay \& HNHM); 3 males, Govi Altay aimak, Mts Adz Bogd, valley of Ih-gol, 2100 m, N4445', E9500’, 17.V.1990, leg. Gy. Fábián, M. Hreblay, L. Peregovits \& G. Ronkay (coll. G. Ronkay, Z. Varga \& HNHM); 1 female, Govi Altai aimak, 1880 m, 7.VI.2004, leg. Saldaitis (coll. P. Gyulai); 3 males, Govi Altay aimak, N slopes of Adz Bogd Mts, 1880 m, 8.VI.2004, leg. Saldaitis (coll. P. Gyulai); 1 male, 1 female, Govi Altai, $20 \mathrm{~km}$ NWW of Bidzh village, Hundlengijn-Shin place, $1650 \mathrm{~m}$, 5.VI.2011, leg. R. Yakovlev (coll. NHM Wien); 1 male, 1 female, Mongolian Altai Mts, S slope Mongoljn-Gol valley, 1800 m, 31.V.2011, leg. R. Yakovlev (coll. NHM Wien), 1 male, Govi Altay Aimak, S. of Mongolian Altay, Mogoin gol river, 1920 m, 8-9.VII.2004, leg. Saldaitis (coll. P. Gyulai).

Slide Nos: VZ5931m, VZ5932m, VZ9489m, VZ9502m (males), VZ9510f (female).

Diagnosis - Ctenoceratoda persephone is on average the largest species of the khorgossi-group (with its wingspan $38-42 \mathrm{~mm}$ ) and is externally also most similar to C. khorgossi (Figs 5-6) but the whole appearance is more robust, the colouration is grey, in fresh specimens often with some light bluish hue but never ochreous-brown as in C. khorgossi. The dark markings are blackish graphite-grey; the lighter parts of the wing are whitish-grey. Reniform stigma slightly curved, with a pipe-shaped acute whitish stripe at lower extremity; claviform stigma very short, with whitish-grey "wish" terminally. Brush organ of the male reduced.

The most important specific differences in the male genitalia of $C$. persephone (Figs 33, 34) are as follows: ampulla elongate and slightly falcate, not acute and plate-shaped as in C. khorgossi (Figs 35, 36); head of cucullus relatively large and not inflated terminally as in C. argyrea (Figs 37, 38).

In the female genitalia, the appendix bursae is larger and longer than in the related species (Figs 39-42).

Bionomics and distribution - Mostly unknown. The type-series was collected at medium-high altitude of the Mongolian Altai (Mongol and Govi Altai) Mts. The species has an early appearance in the year, the flight period is the late spring, in most parts of Mongolia it is in May-early June.

Etymology. Persephone is a spirit of the spring in Greek mythology. 

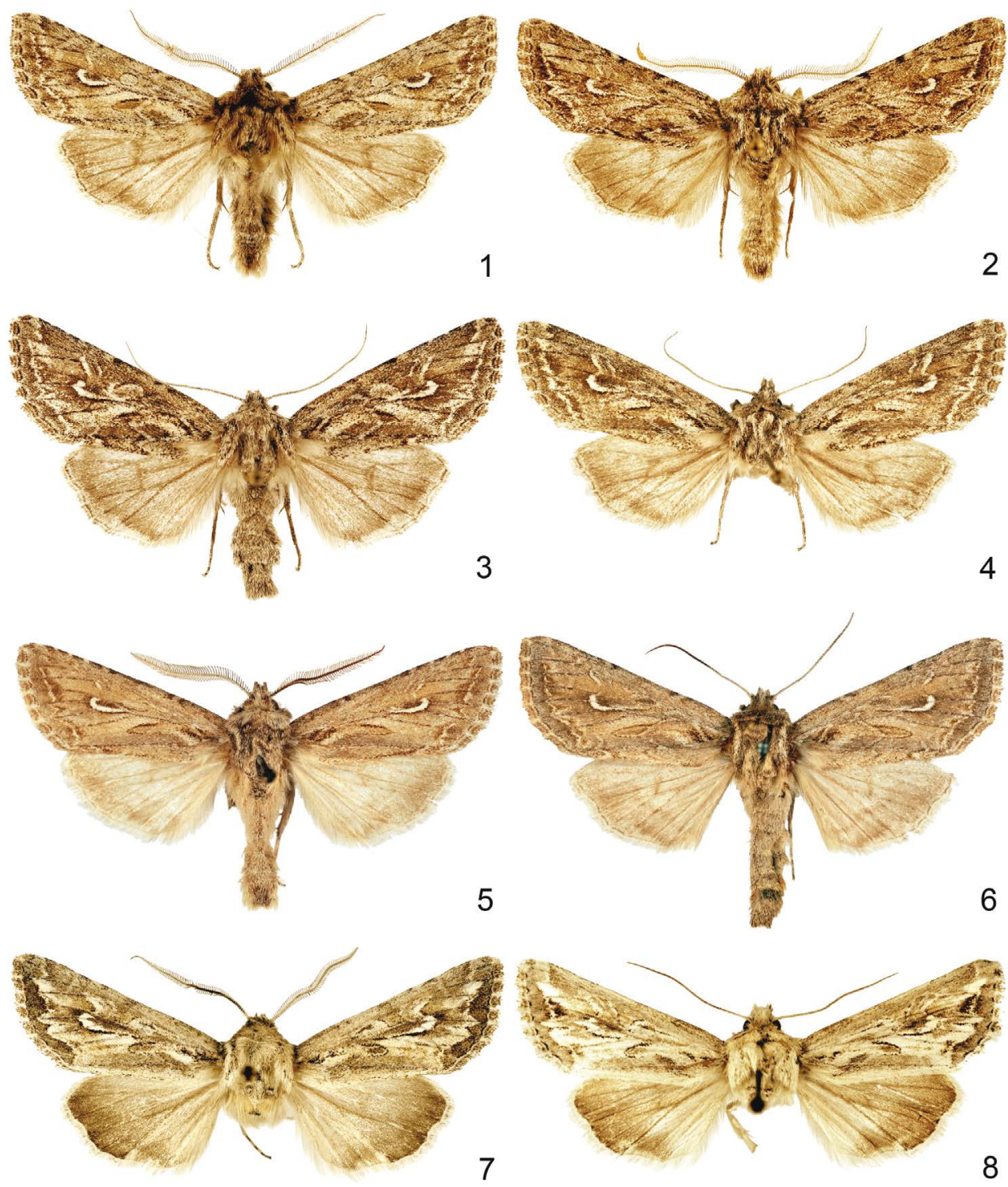

Figs 1-8. Ctenoceratoda spp. 1-4 = C. persephone sp. n., Mongolia: $1=$ paratype, male, Khovd aimak, 2 = holotype, male, Govi Altay aimak, 3 = paratype female, Khovd aimak, 4 = paratype, female, Khovd aimak; 5-6 = C. khorgossi (Alphéraky, 1882), Kirghisia, Issyk-Kul: 5 = male, 6 = female; $7-8=$ C. argyrea (Varga, 1992), Mongolia, Govi Altay aimak: 7 = holotype, male, $8=$ paratype female 

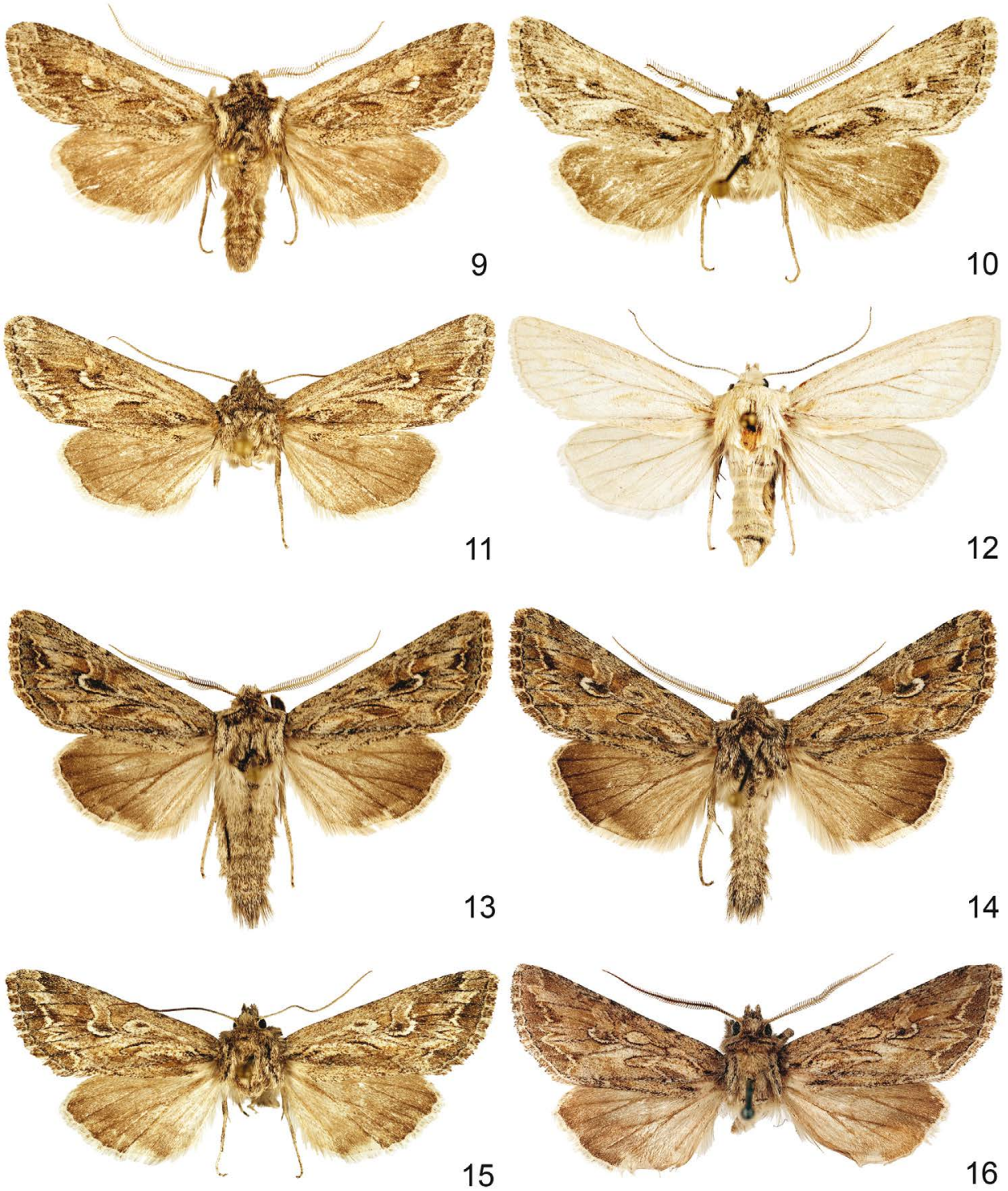

Figs 9-16. Ctenoceratoda spp. 9-12 = C. scotosparsa, sp. n., Mongolia, Govi Altay aimak: 9-10 = paratype, male, $11-12=$ paratype, female; $13-15=$ C. cyanochrea $\mathrm{sp}$. $\mathrm{n}$. , Mongolia, Khovd aimak: 13 = holotype, male, 14 = paratype, male, 15 = paratype, female; $16=$ C. graeseri (Püngeler, 1898), lectotype, male, "Asia centr. Ili geb." 

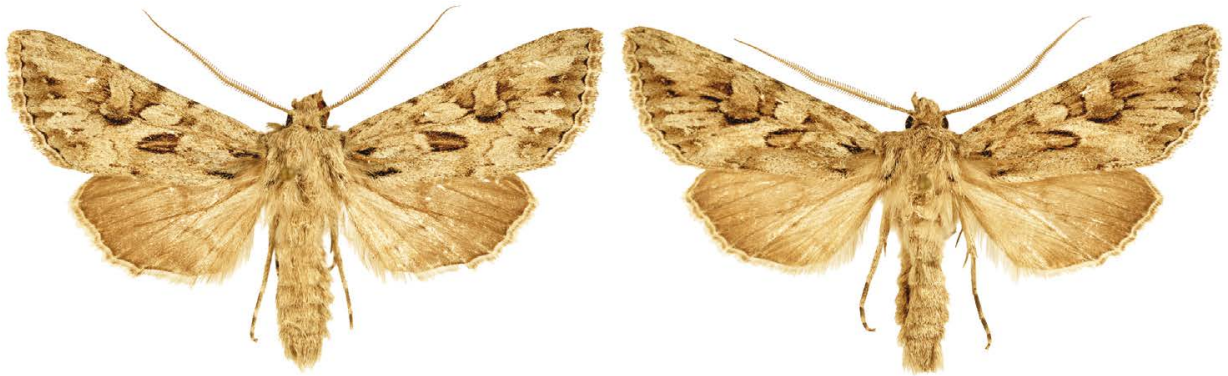

17
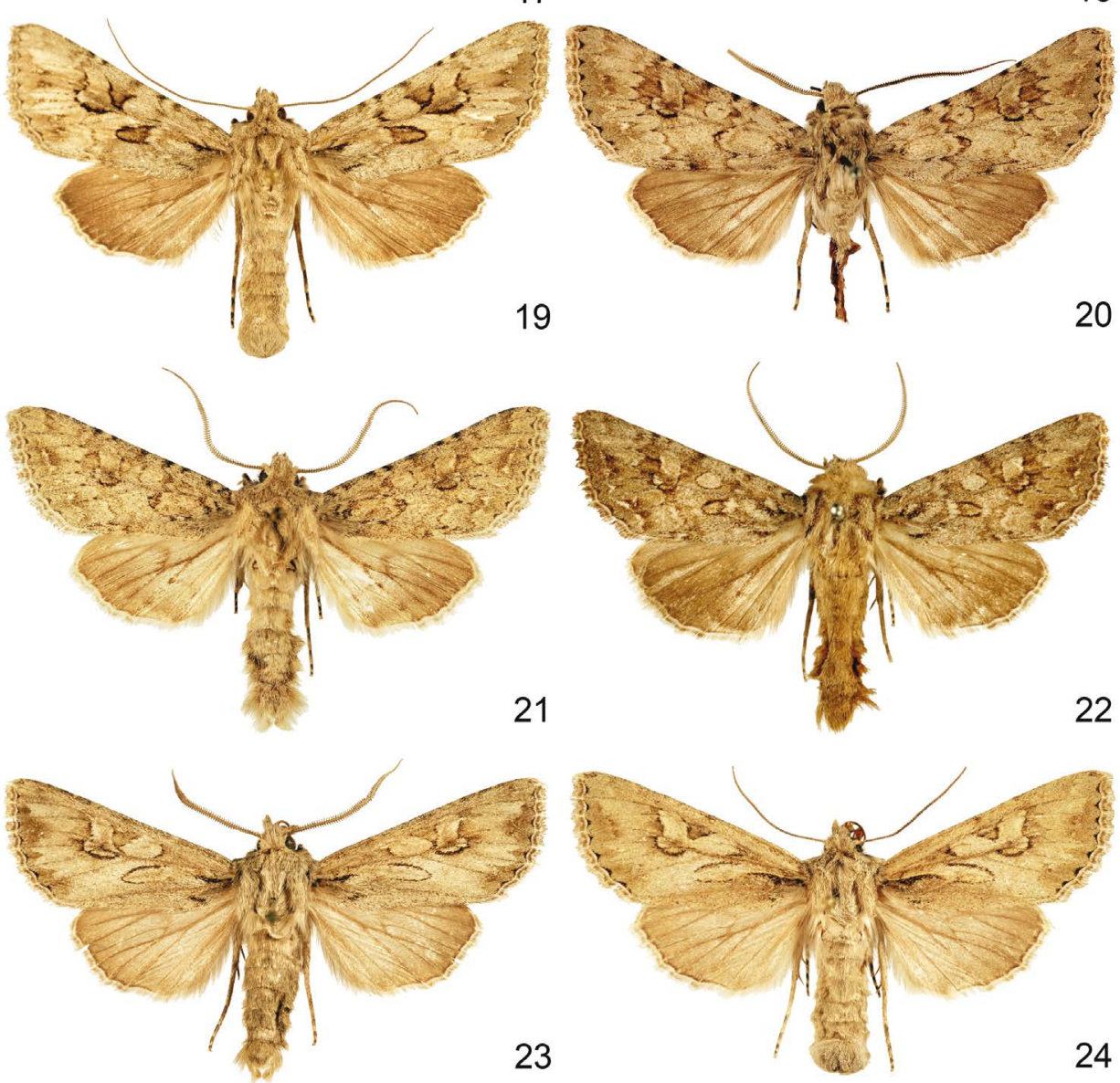

Figs 17-24. Ctenoceratoda spp. 17-19= Ctenoceratoda mallopyga mallopyga sp. n., 17-18= paratype, male, Pakistan, 19 = paratype, female, Pakistan, Hindukush Mts; $20=C$. contempta (Püngeler, 1914), lectotypel male, [China, Xinjiang] "Ost-Turkestan, Aksu"; $21=$ C. septemlacustris Gaal-Haszler, Lödl, Ronkay, Ronkay \& Varga, 2012, holotype, male, Afghanistan, Koh-i-Baba Mts; 22 = C. lupa (Christoph, 1893), lectotype, male, [Iran] Hyrcania, Shahkuh; 23-24 = C. mallopyga dyschroa ssp. n., India, Himachal Pradesh: $23=$ holotype, male, $24=$ paratype, female 


\section{Ctenoceratoda scotosparsa sp. $\mathrm{n}$.}

(Figs 9-12, 27, 42-46)

Holotype: male, Mongolia, Govi Altai aimak, Mongolian Altay Mts, Sutay uul, $16 \mathrm{~km}$ SE of Dzuyl, 46¹1’N, 9401’E; 2070 m, 28.VI.2005, leg. T. Csővári (coll. P. Gyulai, Miskolc).

Paratypes. Mongolia. 17 males, 2 females, from the same locality as the holotype, 28.VI. and 4.VII.2005, leg. T. Csővári (coll. T. Csővári, P. Gyulai, G. Ronkay, Z. Varga and HNHM); 3 males, Govi Altai aimak, 45 km SE Biger, 1850 m, 5.VI.2004, leg. Saldaitis (coll. P. Gyulai), 2 males, Govi Altay aimak, N slope of Adz Bogd Mts, 1880 m, 8.VI.2004, leg. Saldaitis (coll. M. Dvořák, Smrcna, Czech Republic).

Slide Nos: GYP1739m; RL8644m, VZ7678m, VZ9491m, VZ9492m, VZ9521m (males), VZ9508f, VZ9509 (females).

Diagnosis - Ctenoceratoda scotosparsa is on average the smallest species of the khorgossi-group with its wingspan 33-38 mm. It is most closely related to C. argyrea (Figs 7-8) but is smaller in size and more narrow-winged, the light ochreous-grey ground colour of the forewing is irrorated with whitish and blackish-brown scales, and the entire wing is less shiny than in C. argyrea. The maculation is also different: reniform stigma finely blackish defined, with blackish-brown filling and an L-shaped whitish spot basally, without "pipeshaped" elongate whitish stripe like in C. argyrea and C. khorgossi. The claviform stigma is unicolorous blackish-brown, being very different from those of all other species of the species-group (and the whole genus). The inner side of the subterminal line is followed by sharp black arrowheads. The hindwings are more unicolorous and darker than in all related species.

The male genitalia (Figs 43-46) are also proportionally smaller than in the related species, the "head" of the cucullus is not inflated than in C. argyrea and more rounded than in C. cyanochrea (Figs 47-48). The ampulla is relatively broad, slightly curved and rounded terminally; the fascia of cornuti in vesica is shorter than in the related species, as well as the appendix bursae in the female genitalia (Fig. 42).

Distribution and bionomics. Mostly unknown. The type-series was collected at medium-high altitude of the Mongolian Altai Mts; the flight period is the early summer.

\section{Ctenoceratoda cyanochrea sp. $\mathrm{n}$.}

(Figs 13-15, 29, 47, 48, 59)

Holotype: male, Mongolia, Khovd aimak, Mongolian Altay Mts, 1430 m, Mönkh Khayrkhan uul, $41 \mathrm{~km} \mathrm{~N}$ of Bulgan; N46 $28^{\prime}$, E91 $24^{\prime}$; 30.VI.2005, leg. T. Csővári (coll. G. Ronkay).

Paratypes. Mongolia. 4 males, with the same data (coll. T. Csővári, P. Gyulai, G. Ronkay \& Z. Varga); 7 males, Khovd aimak, Dzhungarian Gobi, 81 km SW of Dzuyl, N4545', E93¹5’, 29.VI.2005, leg. T. Csővári (coll. T. Csővári, G. Ronkay \& HNHM); 4 specimens, Govi Altai aimak, Mongolian Altay Mts, Sutay uul, $16 \mathrm{~km}$ SE of Dzuyl, $46^{\circ} 11^{\prime} \mathrm{N}, 9^{\circ} 01^{\prime} \mathrm{E}$; 
2070 m, 28.VI.2005, leg. T. Csővári (coll. T. Csővári); 1 male, 1 female, Govi Altai aimak, Mogoin gol river, 1920 m, 15-18.VI.2004, leg. Saldaitis (coll. P. Gyulai \& M. Dvořák); 3 males, Govi Altay Aimak, S. of Mongolian Altay, Mogoin gol river, 1920 m, 8-9.VII.2004, leg. Saldaitis (coll. P. Gyulai); 1 male, 1 female, Govi Altai aimak, Mongol Altay Mts, $16 \mathrm{~km}$ SE of Tonhil, N46¹1,348, E94º0,955, 2032 m, 29.VII.2006, leg. leg. J. Babics, B. Benedek \& A. Kun (colls P. Gyulai \& G. Ronkay).

Slide Nos: RL8645m, VZ7439m, VZ9490m (males), VZ9507f (female).

Diagnosis - The new species resembles externally certain members of the tancrei-group but has more vivid bluish-grey colouration and complete pattern. It appears as on average much larger than the former species (wingspan $39-42 \mathrm{~mm}$ ) and usually somewhat larger than the externally also similar $C$. argyrea, occurring with them sympatrically.

Ctenoceratoda cyanochrea can be distinguished from C. argyrea by its less curved reniform stigma having relatively shorter acute whitish spot basally; stronger defined, ochreous orbicular stigma (it is obsolescent in C. argyrea); longer, terminally acute claviform stigma; and the light ochreous, finely brownish defined (not whitish and diffuse) subterminal line.

The new species differs from the related C. tancrei and C. graeseri (Fig. 16) by its smaller size and the bluish shaded grey ground colour while the larger relatives usually have ochreous-brownish forewings without any bluish hue.

In male genitalia, the most conspicuous character is the relatively large, not inflated rounded triangular "head" of the cucullus (Figs 47, 48). Aedeagus and vesica is much larger than in the former species. Brush organ is well developed, opposed to the externally similar species of the C. khorgossi-group, e.g. C. scotosparsa and C. argyrea. Based on this character, this species cannot be mixed with either species of the $C$. sukharevae-group since latter never have any brush organ.

Distribution and bionomics. The type series of the new species was collected at lower altitudes of the Mongolian Altai Mts. Its flight period is the mid-summer.

\section{Ctenoceratoda mallopyga sp. $\mathrm{n}$.}

(Figs 17-20, 31, 49, 50, 60)

Holotype: male, Pakistan, Karakoram Mts, Naltar valley, 2800 m, 36 $09^{\prime} \mathrm{N}, 74^{\circ} 12^{\prime} \mathrm{E}$, 30.VI.2000, leg. Z. Varga et G. Ronkay (coll. Z. Varga, Debrecen).

Paratypes. Pakistan. 8 males, 3 females, with the same data as the holotype; 1 female, from the same locality, 7.VII.2000, leg. Z. Varga \& G. Ronkay; 1 female, from the same locality, 14.VIII.1998, leg. Z. Varga \& G. Ronkay; 1 male, from the same locality, 15.VI.1998, leg. Gy. Fábián \& B. Herczig; 1 female, from the same locality, 14.VIII.1998, leg. Z. Varga \& G. Ronkay; 5 males, 4 females, from the same locality, 18.VII.1998, leg. G. Csorba \& L. Ronkay; 2 males, Karakoram Mts, Naltar valley, 2000 m, N3609', E74¹0', 16.VII.1994, leg. B. Herczig, Gy.M. László \& G. Ronkay; 21 males, 27 females, Karakoram Mts, Hispar valley, Huru, 

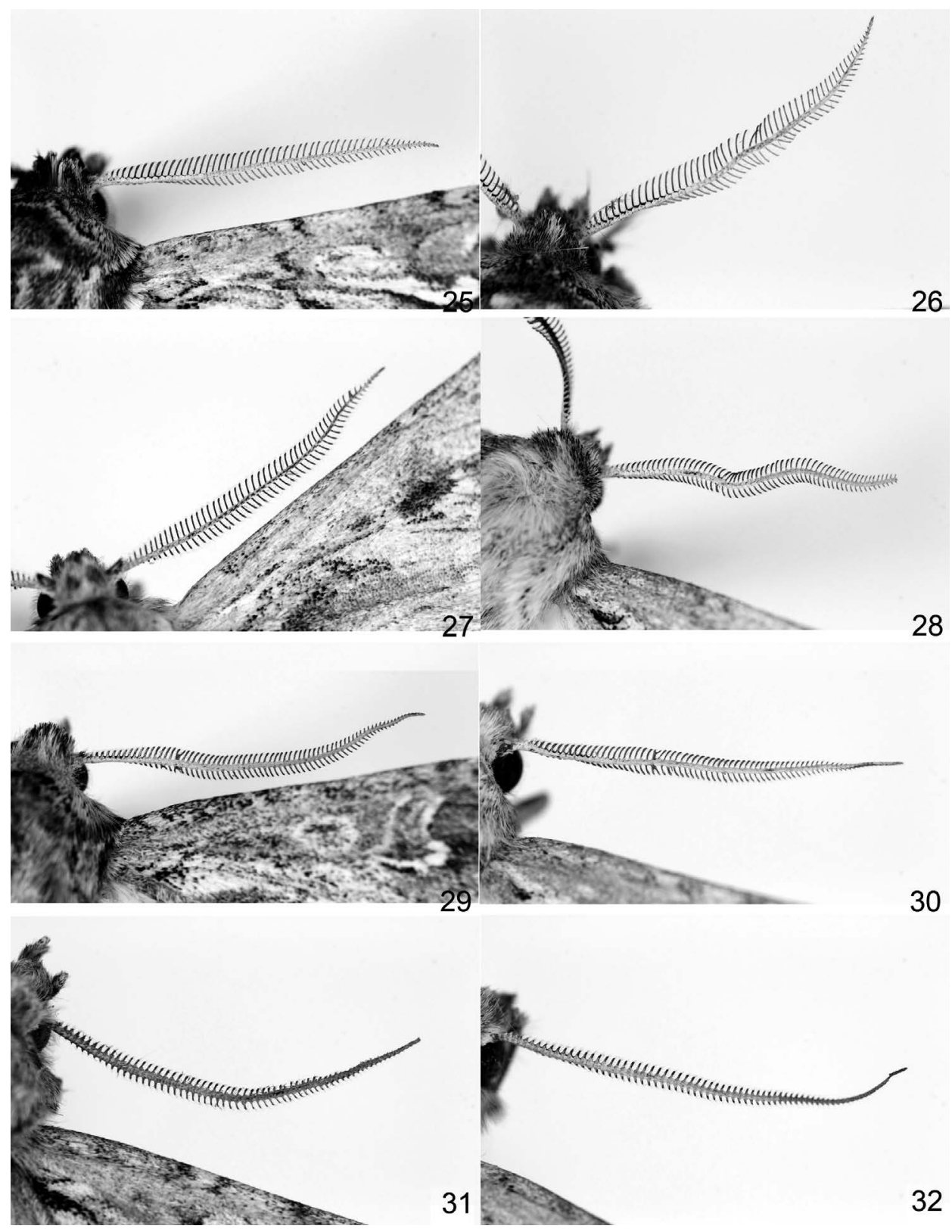

Figs 25-32. Ctenoceratoda spp. antennae. $25=$ C. persephone sp. n., paratype, male, Mongolia, $26=$ C. khorgossi (Alphéraky, 1882), male, Kazakhstan, $27=$ C. scotosparsa sp. n., paratype, male, Mongolia, $28=$ C. argyrea (Varga, 1992) holotype, male, Mongolia, $29=$ C. cyanochrea sp. n., paratype, male, Mongolia, $30=$ C. tancrei (Graeser, 1892), male, Kazakhstan, $31=$ C. mallopyga mallopyga sp. n., paratype, male, Pakistan, $32=$ C. contempta (Püngeler, 1914), male, Kirghisia 

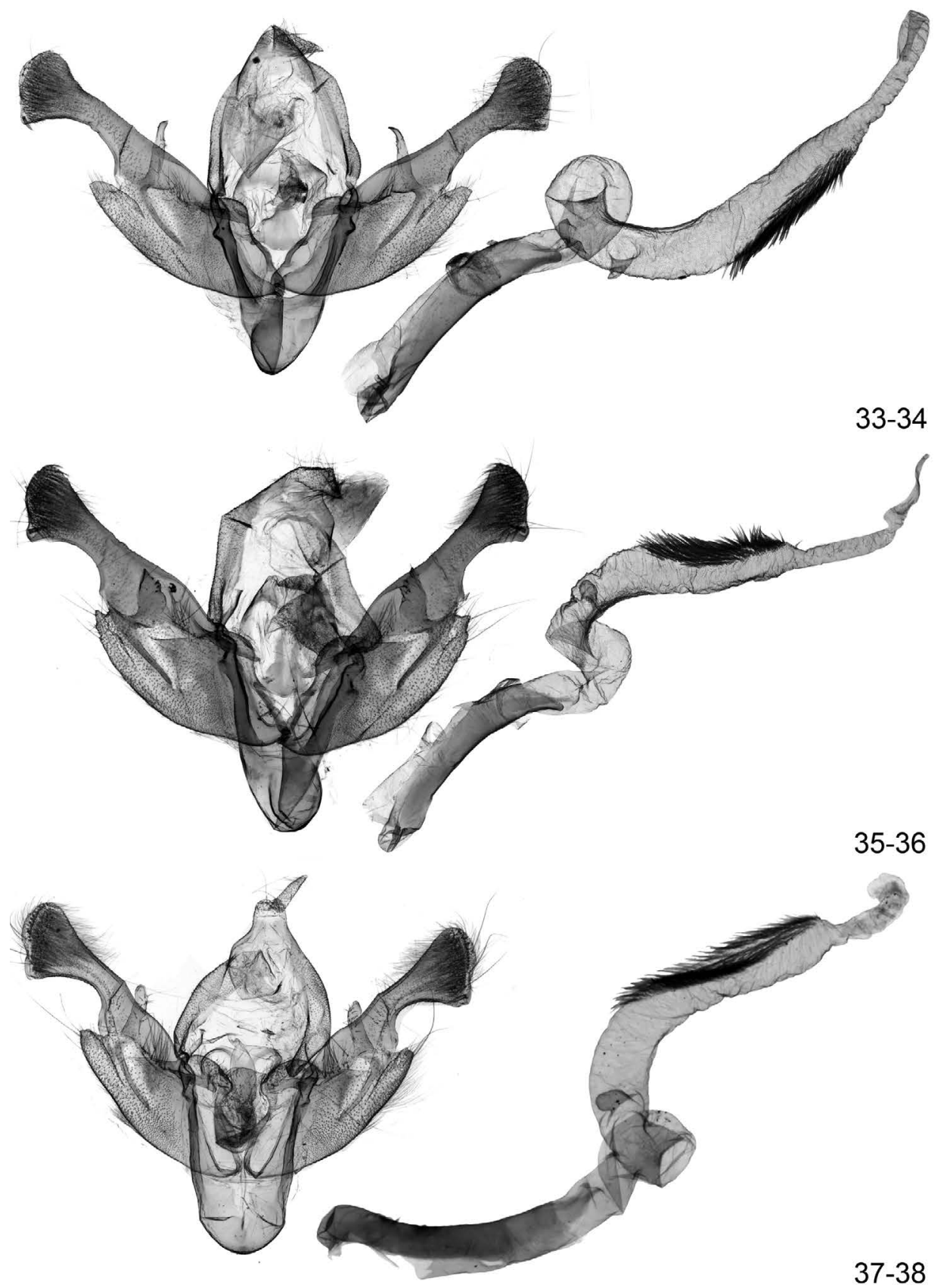

Figs 33-38. Ctenoceratoda spp. male genitalia. 33-34=C. persephone sp. n., paratype, Mongolia, slide No.: VZ9489; 35-36 = C. khorgossi (Alphéraky, 1882), Kirghisia, slide No.: VZ9488; 37-38 = C. argyrea (Varga, 1992), paratype, Mongolia, slide No.: VZ5109 
N36¹5’, E74²4', 23.VII.1994, leg. B. Herczig, Gy.M. László \& G. Ronkay; 1 female, Darkot, 10.VIII.1998, leg. Z. Varga \& G. Ronkay; 1 male, 1 female, Teru, 14.VII.1994, leg. B. Herczig, Gy.M. László \& G. Ronkay (coll. P. Gyulai, G. Ronkay, Z. Varga and HNHM); 4 females,
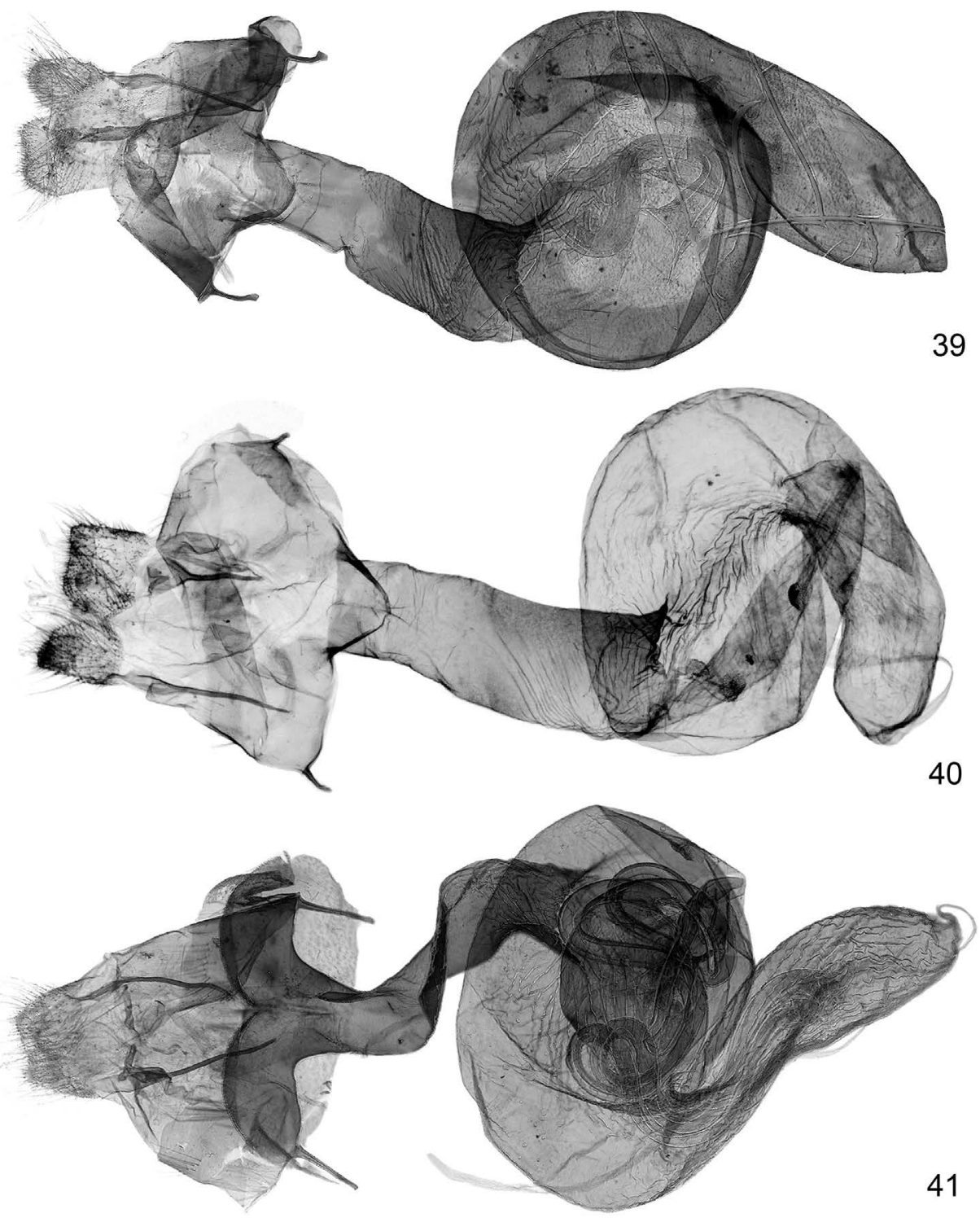

Figs 39-41. Ctenoceratoda spp. female genitalia. 39 = C. persephone sp. n., paratype, Mongolia, slide No.: VZ5942; 40 = C. khorgossi (Alphéraky, 1882), Kazakhstan, slide No.: VZ9506; $41=$ C. $\operatorname{argyrea}($ Varga, 1992), paratype, Mongolia, slide No.: VZ5153 

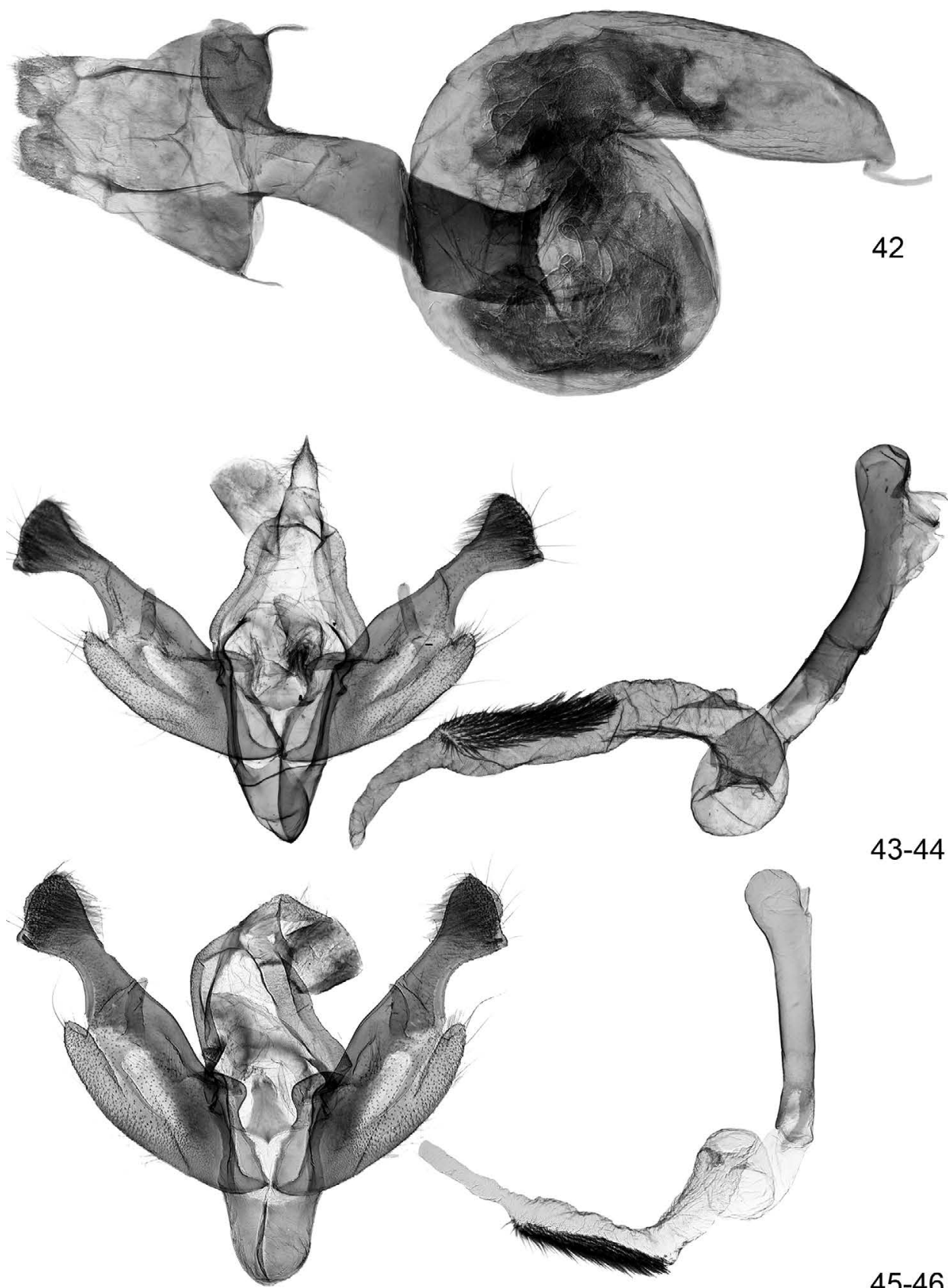

Figs 42-46. Ctenoceratoda scotosparsa sp. n., genitalia, paratype, Mongolia. 42 = female, slide No.: VZ9508; 43-44 = male, slide No.: VZ9492, 45-46 = male, slide No.: RL8644 
Karakoram Mts, Juglot valley, 2550 m, 26.VII.2011; 20 males, Karakoram Mts, Chaprot village, 2400 m, 29.VI.2014 (coll. P. Gyulai).

Slide Nos: VZ7435m, VZ7494m, VZ9173m, VZ9238m, VZ9245m, VZ9823m (males), VZ7487f (female).

Diagnosis - Ctenoceratoda mallopyga is on average the largest and the most colourful member of the C. lupa-group (wingspan 43-51 mm) having broad forewing and robust body. Ground colour of body and forewings variably dark whitish-grey, the lighter parts have some bluish shade while the darker parts of the thorax and the forewing are covered with darker graphite-grey scales. The forewing pattern is rather similar throughout the members of the lupa-group but the colouration is not brownish or ochreous as in the closely related C. contempta (Fig. 20), C. lupa (Fig. 21) and C. septemlacustris (Fig. 22) but more bluish or (in worn specimens) slate-grey. The basal part of reniform stigma is more prominently marked with blackish scales than in the related taxa while the claviform stigma is longer and stronger defined with blackish. The crosslines are reduced; the postmedial line is distinctly marked with black arrowheads. Hindwings light grey with darker terminal band.

The male genitalia (Figs 49,50) are basically similar to those of the related species, but the "head" of the cucullus is relatively larger than in C. contempta, C. septemlacustris and C. lupa (Figs 51-56) and the ampulla is longer and not acute as in the three allied taxa but slightly curved and obtuse terminally.

Distribution and bionomics. The new species occurs in the southern Pamirs (Wakhan valley), the eastern Hindukush (east of the Shandur pass), the Karakoram Mts (type locality) and the western Himalayas. It inhabits the medium-high and higher altitudes (between 2000-2800 m), the moths are local but rather frequent in their habitats.

\section{Ctenoceratoda mallopyga dyschroa ssp. $\mathrm{n}$.}

$$
\text { (Figs 23, 24, 57, 58, 61) }
$$

Holotype: male, India Himachal Pradesh, Spiti, Spiti valley, 6 km SE Kaza, 4100 m, 1.VII.1994, No. 21, leg. P. Kautt \& V. Weisz (coll. G. Ronkay).

Paratypes. India, Himachal Pradesh. Spiti, Spiti valley: 4 males, 3 females, with the same data as the holotype; 1 male, Kaza, 3600 m, 19.VI.1994 (No. 4); 1 female, Kaza, 3600 m, 29.VI.1994 (No. 19); 1 male, 2 females, 3 km SE Kaza, 3900 m, 30.VI.1994 (No 20); 1 male,

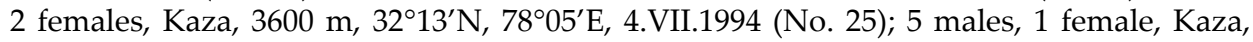
3600 m, 32¹3’N, 7805'E, 5.VII.1994 (No. 27); 1 male, Kaza, 3600 m, 6.VII.1994 (No. 29); 1 male, 5 km WNW Kaza, 4350 m, 10.VII.1994 (No. 33); 1 male, 1 km SW Komik, 4400 m, 11.VII.1994 (No. 34); 1 male, Kaza, 3600 m, 12.VII.1994 No. 35); 3 males, 2 females, Kaza, $3600 \mathrm{~m}, 32^{\circ} 13^{\prime} \mathrm{N}, 78^{\circ} 05^{\prime} \mathrm{E}, 13 . \mathrm{VII} .1994$ (No. 36); 1 male, Kaza, 3600 m, 32 ${ }^{\circ} 13^{\prime} \mathrm{N}, 78^{\circ} 05^{\prime} \mathrm{E}$, 14.VII.1994 (No. 38); 2 females, 1 km NW Kaza, 3550 m, 15.VII.1994 (No. 39); 1 female, Kaza, 3600 m, 32¹3’N, 7805’E, 15.VII.1994 (No. 40); 6 males, 2 females, 6 km SE Kaza, 4100 

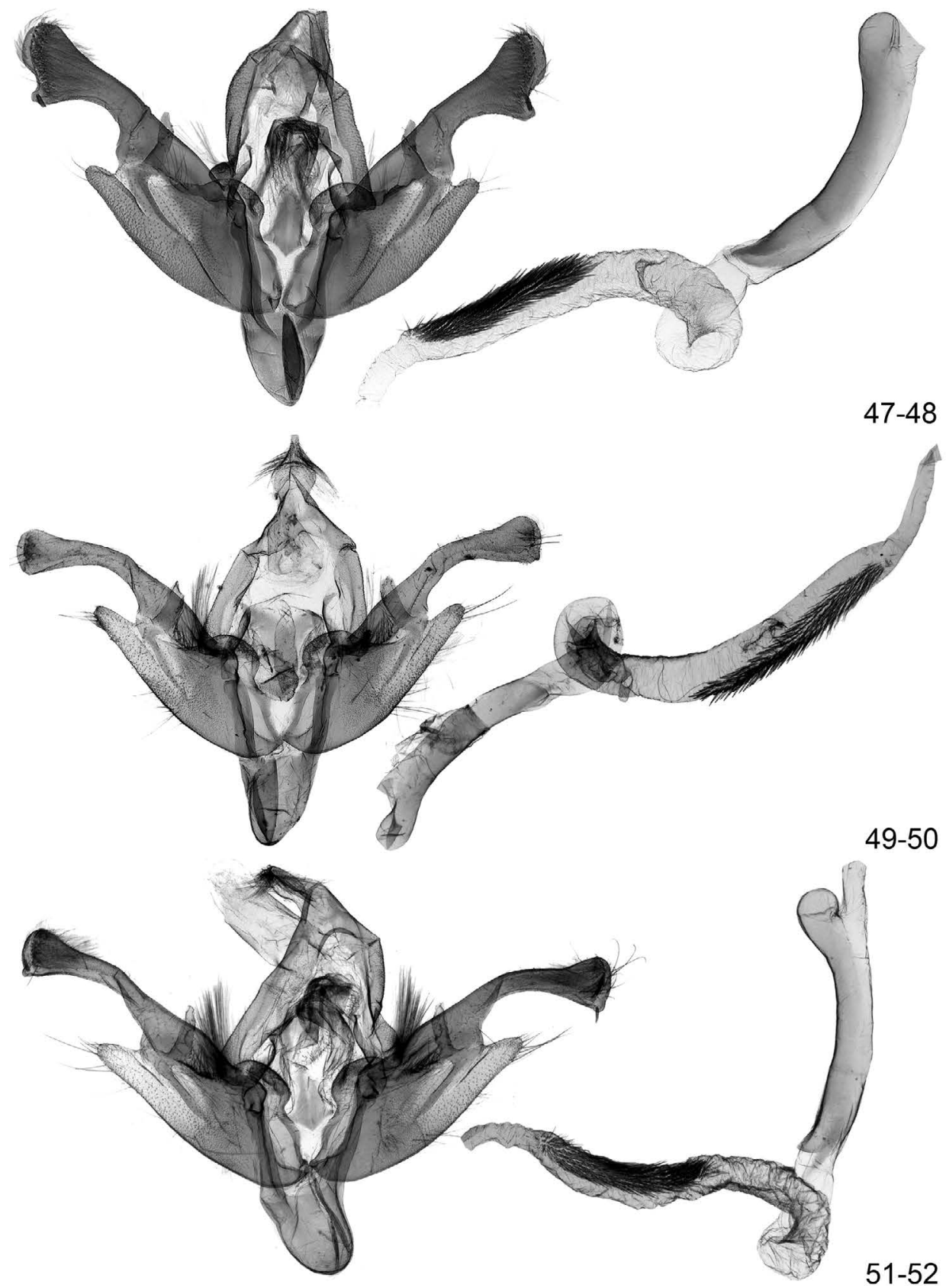

Figs 47-52. Ctenoceratoda spp. male genitalia. 47-48 = C. cyanochrea sp. n., paratype, Mongolia, slide No.: RL8644; 49-50 = C. mallopyga mallopyga sp. n., paratype, Pakistan, slide No.: VZ9238; 51-52 = C. contempta (Püngeler, 1914), Semiretshye, slide No.: RL11754 


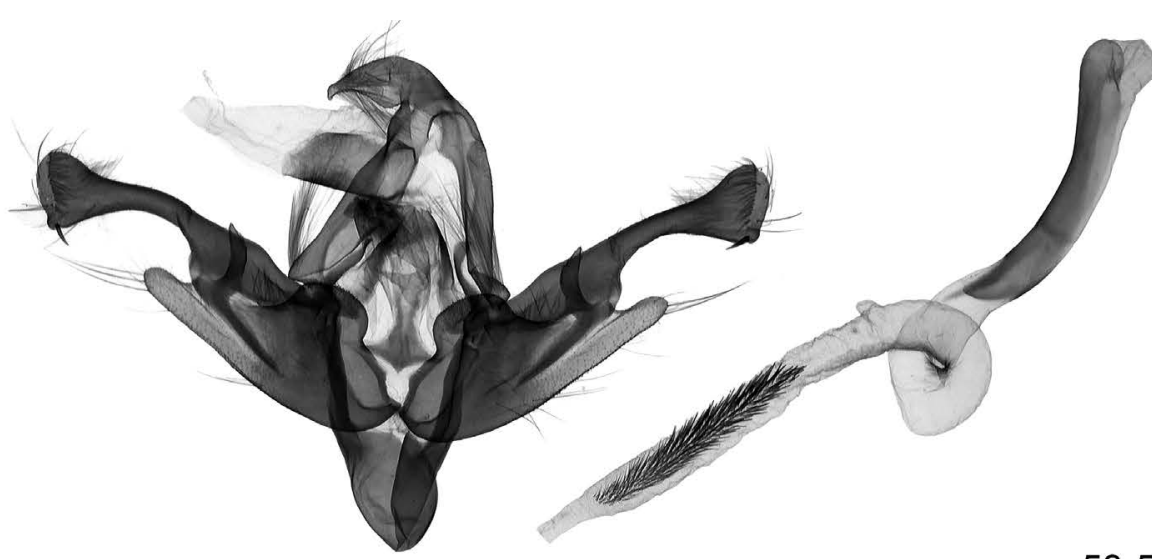

$53-54$

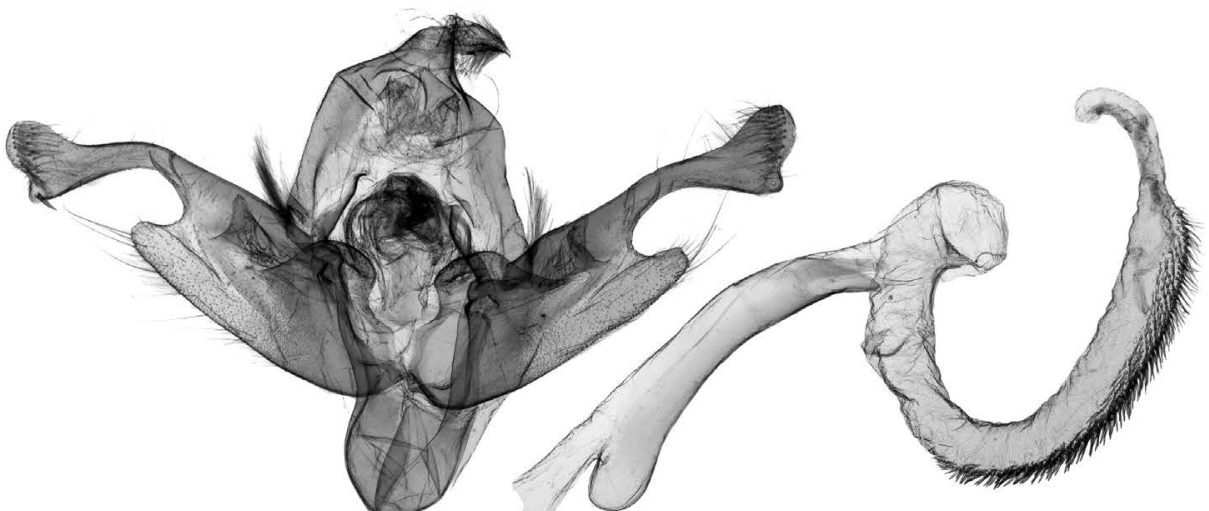

$55-56$

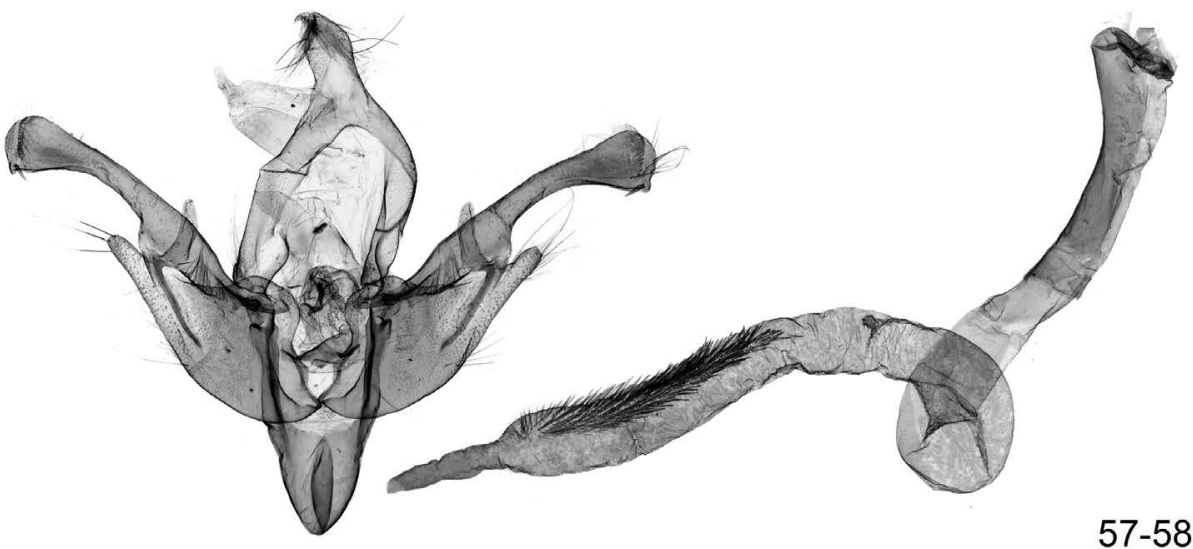

Figs 53-58. Ctenoceratoda spp. male genitalia. 53-54 = C. septemlacustris Gaal-Haszler, Lödl, Ronkay, Ronkay et Varga, 2012, paratype, Afghanistan, slide No.: RL10476; 55-56 = C. lupa (Christoph, 1893), Iran, slide No.: RL11753; 57-58 = C. mallopyga dyschroa sp. n., paratype, India Himachal Pradesh, slide No.: VZ9530 
m, 17.VII.1994 (No. 41); 2 males, 7 km SE Kaza, 4150 m, 18.VII.1994 (No. 42 ); 1 female, Kaza,

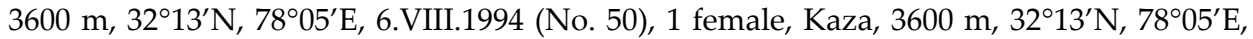
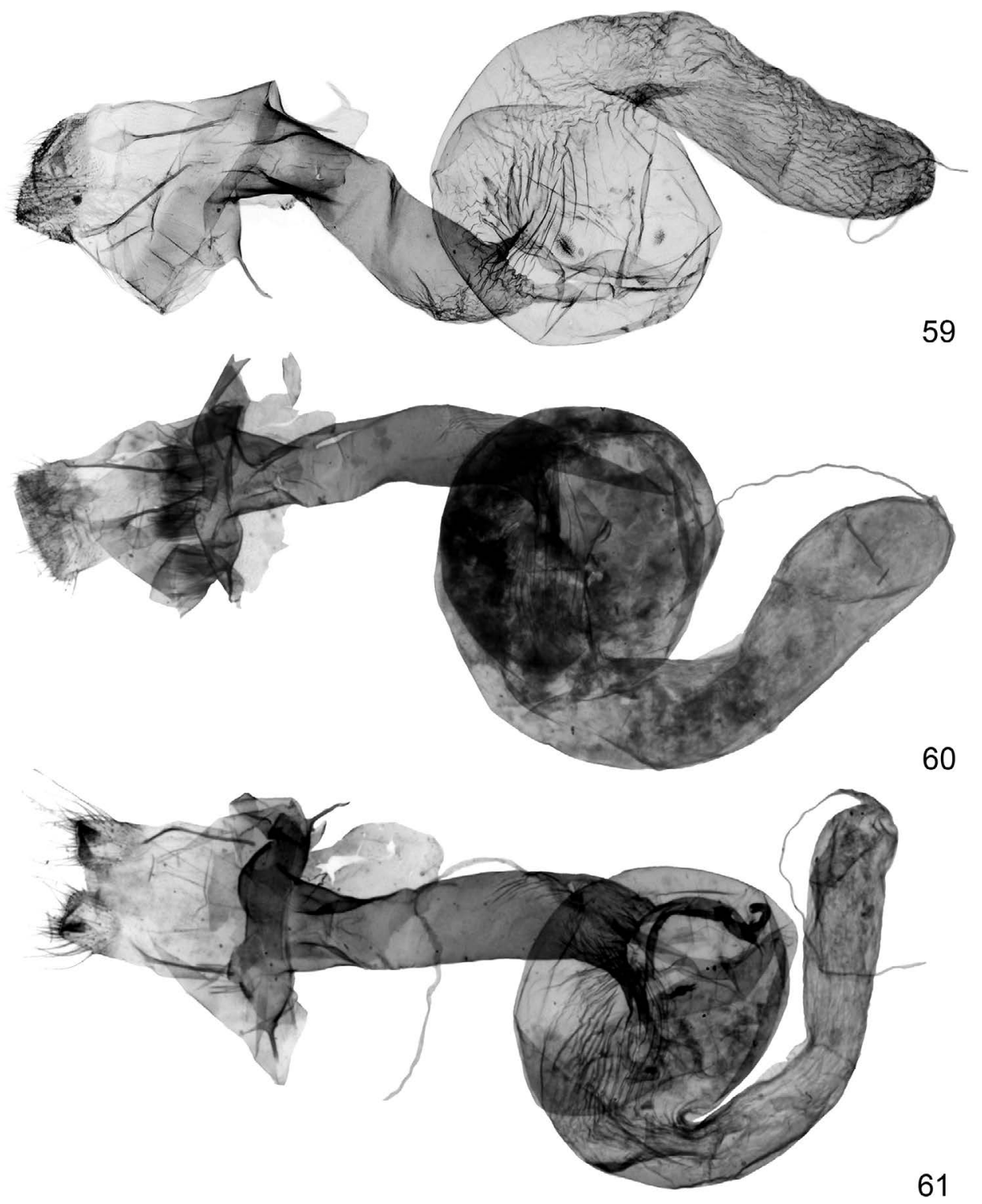

Figs 59-61. Ctenoceratoda spp. female genitalia. $59=$ C. cyanochrea sp. n., paratype, Mongolia, slide No.: VZ9507; 60 = C. mallopyga mallopyga sp. n., paratype, Pakistan, slide No.: VZ7487; 61 = C. mallopyga dyschroa sp. n., paratype, India Himachal Pradesh, slide No.:

VZ7485 
7.VIII.1994 (No. 52) (coll. P. Gyulai, G. Ronkay and HNHM); altogether 45 specimens from the above-mentioned localities, in coll. H. Hacker.

Slide Nos: VZ7681m, VZ8008m, VZ9530m (males), VZ7485f (female).

Diagnosis - The subspecies has the same appearance and regular pattern as the nominotypical subspecies but is essentially smaller in size (wingspan $42-46 \mathrm{~mm}$ ) and lacks the bluish-grey colouration of body and forewings which is typical of the ssp. mallopyga. The body and the wings are unicolorous clay-grey, thorax with scattered blackish-brownish hairs, abdomen slightly lighter, somewhat more ochreous. Pattern of forewing regular, maculation finely defined with black scales, basal part of reniform stigma and the entire claviform stigma stronger defined; basal dash black, root-shaped.

Ctenoceratoda mallopyga dyschroa can be distinguished from the other members of the lupa-group by the rather unicolorous forewings with complete and regular pattern.

The male genitalia (Figs 57,58) are proportionally smaller than those of the ssp. mallopyga, displaying no mentionable differences between the two subspecies.

Distribution and bionomics. The new subspecies is confined to a relatively small, semi-arid area in the south-western Himalaya Mts in India (Himachal Pradesh). It seems to be locally frequent at the high altitude regions (between 3500-4200 m a.s.1.).

Acknowledgements - The present survey was financially supported by the Grant No. K116694 of the National Foundation of Research, Development and Innovation (NKFIOTKA). The studies were partly supported by the SYNTHESYS Project which is financed by European Community Research Infrastructure Action under the FP6 "Structuring the European Research Area" Programme; Grants Nos GB-TAF-2644, DE-TAF-3514 and ATTAF-5609 (G. Ronkay); GB-TAF-2656, GB-TAF-5870 and FR-TAF-562 (L. Ronkay).

The authors are indebted to Martin Honey and Alberto Zilli (London), Robert Trusch, Günter Ebert and Michael Falkenberg (Karlsruhe), Wolfram Mey (Berlin), Matthias Nuss (Dresden), Thomas Schmitt (Müncheberg), Hermann-Heinrich Hacker (Staffelstein), Axel Hausmann and Ulf Buchsbaum (Munich), Dieter Stüning and the late Clas Naumann (Bonn), Erik von Nieukerken and Rob de Vos (Leiden), Ole Karsholt (Copenhagen), the late Michael Fibiger (Sorø), Bernard Landry (Geneva), Marek Dvořák (Smrcna, Czech Republic), Martin Lödl and Sabine Gaal-Haszler (Vienna), Alexej Matov and the late Irina Leonidovna Sukhareva (St. Petersburg) and Anton Volynkin (Barnaul) for all their kind help during the revisional work of the genus Ctenoceratoda.

\section{REFERENCES}

Beck, H. (1996): Systematische Liste der Noctuidae Europas (Lepidoptera, Noctuidae). Neue Entomologische Nachrichten 36: 1-122. 
Boursin, $\mathrm{C}_{\text {H. }}$ (1964): Lepidoptera der Deutschen Nepal-Expedition 1955 II. NoctuidaeTrifinae. - Veröffentlichungen der Zoologischen Staatssammlung, München 8: 1-40, Taf. I-XXIII.

Fibiger, M. \& Hacker, H. (2005): Systematic list of the Noctuoidea of Europe (Notodontidae, Nolidae, Lymantriidae, Arctiidae, Erebidae, Micronoctuidae, Noctuidae). - Esperiana 11: 7-92.

Hacker, H., Ronkay, L. \& Hreblay, M. (2002): Noctuidae Europaeae. Hadeninae I. - Entomological Press, Sorø, 456 pp., pls 1-16.

Lafontaine, J. D. \& Schmidt, B. CH. (2010): Annotated check list of the Noctuoidea (Insecta, Lepidoptera) of North America north of Mexico. - ZooKeys 40: 1-238. https:// doi.org/10.3897/zookeys.40.414

McCabe, T. M. (1980): A reclassification of the Polia complex for North America (Lepidoptera: Noctuidae). - New York State Museum, Bulletin 432: i-vi, 141 pp.

VARGA, Z. (1992): Taxonomic notes on the genus Haderonia Staudinger, 1896 with the description of a new genus Ctenoceratoda and four new species (Lep.: Noctuidae). Acta Zoologica Academiae Scientiarum Hungaricae 38: 95-112.

VArga, Z. \& Gyulai, P. (1999): Taxonomy of the genus Ctenoceratoda Varga, 1992 (Lep.: Noctuidae, Hadeninae) with the description of seven new species. - Acta Zoologica Academiae Scientiarum Hungaricae 45 (2): 169-197.

VARGA, Z. \& Ronkay, L. (2013): Structural constraints of secondary asymmetry in male external genitalia of Noctuidae. - Insect Systematics \& Evolution 44: 349-372. https://doi. org/10.1163/1876312X-04402001

Varga, Z., Ronkay, G. \& Ronkay, L. (2017): Annotated taxonomic check list of the Eurasiatic species of the subtribe Poliina (Noctuidae, Noctuinae, Hadenini). - Deutsche Entomologische Zeitschrift 64(2): 133-160. https://doi.org/10.3897/dez.64.21455

Received April 29, 2017, accepted October 17, 2017, published March 30, 2018 